\title{
Penerapan Pembelajaran Berdiferensiasi untuk Meningkatkan Hasil Belajar Siswa pada Mata Pelajaran IPA Pokok Bahasan Tanah dan Keberlangsungan Kehidupan di Kelas IXb Semester Genap SMPN 4 Monta Tahun Pelajaran 2020/2021
}

\author{
Suwartiningsih* \\ SMPN 4 Monta, Bima, Indonesia \\ *Coresponding Author: dzikran.akram@gmail.com \\ Dikirim: 16-06-2021 ; Direvisi: 20-06-2021 ; Diterima: 04-07-2021
}

\begin{abstract}
Abstrak: Penelitian ini bertujuan untuk meningkatkan hasil belajar siswa pada mata pelajaran IPA pokok bahasan tanah dan keberlangsungan kehidupan. Penelitian ini menggunakan pembelajaran berdiferensiasi dengan melibatkan tiga unsur yaitu visual, auditori, dan kinestetik. Penelitian ini merupakan penelitian tindakan kelas yang dibagi menjadi dua siklus dan di awali dengan prasiklus. Setiap siklus terdiri dari perencanaan, pelaksanaan tindakan, obeservasi, evaluasi, dan refleksi. Penelitian dilaksanakan pada siswa kelas IXb semester genap di SMPN 4 Monta Tahun Pelajaran 2020/2021. Adapun hasil penelitian yang dilaksanakan pada 29 orang siswa, pada kegiatan pra siklus jumlah siswa yang tuntas adalah 8 siswa $(27,58 \%)$, sedangkan siswa yang belum tuntas 21 siswa $(72,42 \%)$, dengan nilai rata-rata 55,17. Pada siklus I siswa mengalami peningkatan jumlah siswa yang tuntas 15 siswa $(51,72 \%)$ sedangkan siswa yang belum tuntas berjumlah 14 siswa $(48,28 \%)$ dengan nilai rata-rata 66,55 . Kemudian pada siklus II ini mengalami peningkatan yang sangat tinggi dibandingkan dengan siklus sebelumnya yaitu siswa yang sudah mencapai KKM berjumlah 28 siswa (96,55\%), sedangkan siswa yang belum tuntas berjumlah 1 siswa $(3,45 \%)$ dengan nilai rata-rata 80 . Penelitian ini menunjukan bahwa penerapan pembelajaran berdiferensiasi dapat meningkatkan hasil belajar IPA materi tanah dan keberlangsungan kehidupan pada siswa kelas IXb semester genap di SMPN 4 Monta Tahun Pelajaran 2020/2021.
\end{abstract}

Kata Kunci: pembelajaran berdiferensiasi; hasil belajar; mata pelajaran IPA

\begin{abstract}
This study aims to improve student learning outcomes in science subjects, the subject of soil and life sustainability. This study uses differentiated learning by involving three elements, namely visual, auditory, and kinesthetic. This research is a classroom action research which is divided into two cycles and begins with a pre-cycle. Each cycle consists of planning, implementing actions, observing, evaluating, and reflecting. The research was carried out on even semester IXb students at SMPN 4 Monta for the 2020/2021 academic year. The results of research conducted on 29 students, in pre-cycle activities the number of students who completed was 8 students $(27.58 \%)$, while students who had not completed 21 students $(72.42 \%)$ with an average score of 55.17 . In the first cycle, students experienced an increase in the number of students who completed 15 students $(51.72 \%)$ while students who had not completed were 14 students $(48.28 \%$ ) with an average score of 66.55 . Then in the second cycle, there was a very high increase compared to the previous cycle, namely students who had reached the KKM totaled 28 students (96.55\%), while students who had not completed were 1 student $(3.45 \%)$ with an average score of 80 This study shows that the application of differentiated learning can improve soil science learning outcomes and life sustainability in even semester IXb students at SMPN 4 Monta in the 2020/2021 academic year.
\end{abstract}

Keywords: differentiated learning; learning outcomes; science subjects 


\section{PENDAHULUAN}

Guru Penggerak adalah pemimpin pembelajaran yang menerapkan merdeka belajar dan menggerakkan seluruh ekosistem pembelajaran untuk mewujudkan pendidikan yang berpusat pada siswa. Hal ini sesuai dengan paparan mekanisme Pelaksanaan PGP (Pendidikan Guru Penggerak) angkatan I Tahun 2020.

Pendidikan yang berpusat pada siswa, lebih menekankan aspek proses bagaimana siswa belajar dan efek dari proses belajar tersebut bagi perkembangan siswa itu sendiri khususnya di pembelajaran IPA. Pembelajaran IPA melibatkan keaktifan siswa, baik aktivitas fisik maupun aktivitas mental dan berfokus pada siswa, yang berdasarkan pada pengalaman keseharian. Ilmu Pendidikan Alam (IPA) menekankan pada pengalaman langsung untuk mencari tahu dan berbuat sehingga mampu menjelajahi dan memahami alam di lingkungan sekitar secara ilmiah. Selama belajar siswa akan mempunyai pengalaman belajar yang bermakna sehingga pada tahap ini siswa mampu mengembangkan nilai-nilai dari pembelajaran IPA. Sebagai Calon Guru Penggerak yang tengan menjalani pendidikan guru penggerak (PGP), penulis merasa tertantang untuk ikut mewujudkan pendidikan yang berpusat pada siswa sesuai dengan visi misi guru penggerak. Belajar yang terpusat pada siswa sangat efektif diterpakan pada lingkungan belajar siswa (Sutarto \& Syarifuddin, 2013).

Sebelumnya penulis telah berupaya dalam menerapkan pembelajaran yang menyenangkan dengan menggunakan media-media yang menarik, misalnya media slide PPT dan Video yang ditayangkan melalui LCD projector. Akan tetapi hasil belajar siswa masih rendah. Sedangkan menurut Suryosubroto (2009:1), bahwa: Hasil belajar adalah satuan nilai yang menjadi ukuran untuk menentukan tingkat keberhasilan siswa terhadap hasil belajar dan kriteria ini biasanya didasarkan dengan standar atau ukuran yang ada. Dalam hal ini hasil belajar dikelompokkan dalam dua kriteria yaitu tuntas dan belum. Tuntas apabila hasil yang dicapai siswa dalam tes adalah sesuai dengan KKM yang telah ditetapkan di SMPN 4 Monta yakni 70. Dengan memperhatikan berbagai faktor yang mempengaruhi hasil belajar siswa dan kriteria hasil belajar, maka peranan metode yang dipergunakan dalam proses pembelajaran pada mata Ilmu Pengetahuan Alam (IPA) sangat menentukan hasil belajar siswa. Oleh sebab itu guru sebagai pelaksanaan pembelajaran yang berpedoman pada garis-garis besar program pembelajaran di sekolah dapat menggunakan metode atau cara yang tepat diterima oleh siswa.

Terdapat beberapa permasalahan yang penulis identifikasi yakni:

a. Guru belum menerapkan metode yang memungkinkan siswa untuk mengolah, mengembangkan produk sesuai dengan gaya atau minat dari masing-masing siswa.

b. Aktifitas fisik rendah selama proses pembelajaran.

Berdasarkan uraian di atas dapat diasumsikan bahwa mata pelajaran IPA mempunyai nilai yang sangat strategis dan penting dalam mempersiapkan sumber daya manusia yang unggul, cerdas dan mencintai alam dan lingkungan sekitar untuk itu di perlukan kegiatan pembelajaran yang efektif dan bermakna bagi siswa. Dalam proses pembelajaran ternyata memiliki keunikan yang berbeda beda antara siswa yang satu dengan yang lainnya. Ada siswa yang cepat dalam menangkap pelajaran dan dapat menyelesaikan kegiatan pembelajaran lebih cepat dari yang di perkirakan dan ada juga siswa yang lambat dalam belajar sehingga sering tertinggal pelajaran 
dan memerlukan waktu yang lebih lama dari waktu yang diperkirakan untuk siswa normal.

Untuk mengatasi permasalahan di atas, maka penulis mengajukan untuk menggunakan model pembelajaran berdiferensiasi. Menurut modul 2.1 tentang pembelajaran berdiferensiasi dalam Program Guru Penggerak (PGP): Pembelajaran berdiferensiasi adalah proses atau filosofi untuk pengajaran efektif dengan memberikan beragam cara untuk memahami informasi baru untuk semua siswa dalam komunitas ruang kelasnya yang beraneka ragam, termasuk cara untuk: mendapatkan konten; mengolah, membangun, atau menalar gagasan; dan mengembangkan produk pembelajaran dan ukuran penilaian sehingga semua siswa di dalam suatu ruang kelas yang memiliki latar belakang kemampuan beragam bisa belajar dengan efektif. Proses mendiferensiasikan pelajaran dilakukan untuk menjawab kebutuhan, gaya, atau minat belajar dari masing-masing siswa.

Dari latar belakang tersebut maka permasalahan dalam penelitian ini dirumuskan sebagai berikut: "Bagaimanakah penerapan pembelajaran berdiferensiasi untuk meningkatkan hasil belajar siswa pada mata pelajaran IPA pokok bahasan Tanah dan Keberlangsungan Kehidupan di kelas IXb semester genap SMPN 4 Monta Tahun Pelajaran 2020/2021?”

\section{KAJIAN TEORI}

\section{Pembelajaran Berdiferensiasi}

Tomlinson (2001:1) mengemukakan bahwa pembelajaran diferensiasi berarti mencampurkan semua perbedaan untuk mendapatkan suatu informasi, membuat ide dan mengekspresikan apa yang mereka pelajari. Dengan kata lain bahwa pembelajaran diferensiasi adalah menciptakan suatu kelas yang beragam dengan memberikan kesempatan dalam meraih konten, memproses suatu ide dan meningkatkan hasil setiap murid, sehingga murid-murid akan bisa lebih belajar dengan efektif.

Pada LMS Modul 2.1 PGP (2020), Pembelajaran berdiferensiasi adalah serangkaian keputusan masuk akal (common sense) yang dibuat oleh guru yang berorientasi kepada kebutuhan siswa. Keputusan-keputusan yang dibuat tersebut adalah yang terkait dengan:

1. Bagaimana mereka menciptakan lingkungan belajar yang "mengundang' siswa untuk belajar dan bekerja keras untuk mencapai tujuan belajar yang tinggi. Kemudian juga memastikan setiap siswa di kelasnya tahu bahwa akan selalu ada dukungan untuk mereka di sepanjang prosesnya.

2. Bagaimana guru menanggapi atau merespon kebutuhan belajar siswanya. Bagaimana ia akan menyesuaikan rencana pembelajaran untuk memenuhi kebutuhan belajar siswa tersebut. Misalnya, apakah ia perlu menggunakan sumber yang berbeda, cara yang berbeda, dan penugasan serta penilaian yang berbeda.

3. Manajemen kelas yang efektif. Bagaimana guru menciptakan prosedur, rutinitas, metode yang memungkinkan adanya fleksibilitas. Namun juga struktur yang jelas, sehingga walaupun mungkin melakukan kegiatan yang berbeda, kelas tetap dapat berjalan secara efektif. 
Pembelajaran berdiferensiasi haruslah berakar pada pemenuhan kebutuhan belajar siswa dan bagaimana guru merespon kebutuhan belajar tersebut. Dengan demikian, guru perlu melakukan identifikasi kebutuhan belajar dengan lebih komprehensif, agar dapat merespon dengan lebih tepat terhadap kebutuhan belajar siswa-siswanya.

Tomlinson (2001) menyampaikan bahwa kita dapat mengkategorikan kebutuhan belajar siswa, paling tidak berdasarkan 3 aspek. Ketiga aspek tersebut adalah:

1. Kesiapan belajar (readiness) siswa.

Kesiapan belajar (readiness) adalah kapasitas untuk mempelajari materi baru. Sebuah tugas yang mempertimbangkan tingkat kesiapan siswa akan membawa siswa keluar dari zona nyaman mereka, namun dengan lingkungan belajar yang tepat dan dukungan yang memadai, mereka tetap dapat menguasai materi baru tersebut.

\section{Minat siswa}

Kita tahu bahwa seperti juga kita orang dewasa, siswa juga memiliki minat sendiri. Ada siswa yang minat nya sangat besar dalam bidang seni, matematika, sains, drama, memasak, dsb. Minat adalah salah satu motivator penting bagi siswa untuk dapat 'terlibat aktif' dalam proses pembelajaran. Tomlinson (2001) menjelaskan bahwa mempertimbangkan minat siswa dalam merancang pembelajaran memiliki tujuan diantaranya: a) membantu siswa menyadari bahwa ada kecocokan antara sekolah dan keinginan mereka sendiri untuk belajar; b) menunjukkan keterhubungan antara semua pembelajaran; c) menggunakan keterampilan atau ide yang familiar bagi siswa sebagai jembatan untuk mempelajari ide atau keterampilan yang kurang familiar atau baru bagi mereka, dan; 4) meningkatkan motivasi siswa untuk belajar.

3. Profil belajar siswa

Profil belajar siswa terkait dengan banyak faktor, seperti: bahasa, budaya, kesehatan, keadaan keluarga, dan kekhususan lainnya. Selain itu juga akan berhubungan dengan gaya belajar seseorang. Tujuan dari pemetaan kebutuhan belajar siswa berdasarkan profil belajar adalah untuk memberikan kesempatan kepada siswa untuk belajar secara natural dan efisien. Namun demikian, sebagai guru, kadang-kadang kita secara tidak sengaja cenderung memilih gaya belajar yang sesuai dengan gaya belajar kita sendiri. Padahal kita tahu setiap anak memiliki profil belajar sendiri. Memiliki kesadaran tentang ini sangat penting agar guru dapat memvariasikan metode dan pendekatan mengajar mereka. Penting juga untuk diingat bahwa kebanyakan orang lebih suka kombinasi profil. Menurut Tomlinson (2001), ada banyak faktor yang dapat mempengaruhi pembelajaran seseorang. Berikut ini adalah beberapa yang harus diperhatikan:

- Visual: belajar dengan melihat (diagram, power point, catatan, peta, grafik organisator).

- Auditori: belajar dengan mendengar (kuliah, membaca dengan keras, mendengarkan musik).

- Kinestetik: belajar sambil melakukan (bergerak dan meregangkan tubuh, kegiatan hands on, dsb).

Berdasarkan pemaparan mengenai ketiga aspek dalam mengkategorikan kebutuhan belajar siswa, maka kita dapat menarik kesimpulan bahwa untuk 
mengoptimalkan pembelajaran dan tentunya hasil dari pembelajaran siswa diperlukan pembelajaran yang dikembangkan sesuai dengan kebutuhan belajar siswa.

\section{Pendekatan Pembelajaran Berdeferensiasi}

Menurut Andini (2016) pembelajaran diferensiasi menggunakan berbagai pendekatan (multiple approach) dalam konten, proses dan produk. Dalam kelas diferensiasi, guru akan memperhatikan 3 elemen penting dalam pembelajaran diferensiasi di kelas yaitu (1) Content (input) yaitu mengenai apa yang murid pelajari, (2) Proses yaitu bagaimana murid akan mendapatkan informasi dan membuat ide mengenai hal yang dipelajarinya, (3) product (output), bagaimana murid akan mendemonstrasikan apa yang sudah mereka pelajari. Ketiga elemen tersebut di atas akan dilakukan modifikasi dan adaptasi berdasarkan asesmen yang dilakukan sesuai dengan tingkat kesiapan murid, ketertarikan (interes) dan learning profile.

Terdapat 3 elemen penting yang dilakukan diferensiasi, antara lain:

a. Content, konten berhubungan dengan apa yang akan murid-muird ketahui, pahami dan yang akan dipelajari. Dalam hal ini guru akan memodifikasi bagaimana setiap murid akan mempelajari suatu topik pembelajaran. Misalnya, guru akan mengajarkan matematikan yang mana tujuan objektifnya adalah murid-murid bisa membaca waktu. Dari murid-muridnya di kelas, mungkin guru akan menemukan anak yang belum mengerti mengenai konsep angka, ada juga yang belum mengertai mengenai konsep waktu dan mungkin beberapa muridmurid di kelasnya sudah memahami dan bisa membaca waktu dengan baik. Bagi anakanak yang tingkat kesiapannya sudah siap dan mengerti akan konten yang akan dipelajarinya, hal ini tidak menjadikan masalah bagi murid untuk belajar hal yang sama sesuai dengan konten yang sudah ditentukan. Bagi tingkat kesiapannya belum memahami mengenai konten tersebut, guru perlu melakukan modifikasi dan adaptasi berdasarkan tingkat kesiapan murid tersebut.

b. Process, Proses merupakan cara murid mendapatkan informasi atau bagaimana ia belajar. Dalam arti lain adalah aktivitas murid dalam mendapatkan pengetahuan, pemahaman dan ketrampilan berdasarkan konten yang akan dipelajari. Aktivitas akan dikatakan efektif apabila berdasarkan pada tingkat pengetahuan, pemahaman dan ketrampilan murid. Murid akan bisa mengerjakan dengan sendirinya dan berguna bagi diri mereka sendiri.

c. Product, produk merupakan bukti apa yang sudah mereka pelajari dan pahami. Murid-murid akan mendemostrasikan atau mengaplikasikan mengenai apa yang sudah mereka pahami. Produk akan merubah murid dari "consumers of knowledge to producer with knowledge".

Dalam konteks penelitian ini, peneliti mendesain pembelajaran berdasarkan 3 (tiga) elemen pennting dalam pendekatan berdeferensiasi, dengan mempertimbangkan kondisi siswa, yang selanjutnya dituangkan dalam RPP (terlampir) yang akan dilaksanakan dalam proses pembelajaran.

\section{Hasil Belajar IPA}

Ada beberapa pendapat tentang pengertian hasil belajar salah satunya adalah menurut Dimyati dan Mujiyono (2009), Hasil belajar merupakan hal yang dapat dipandang dari dua sisi, yaitu dari siswa dan dari sisi guru. Dari sisi siswa hasil belajar merupakan tingkat perkembangan mental yang lebih baik bila dibandingkan 
pada saat sebelum belajar. Tingkat perkembangan mental tersebut terwujud pada jenis-jenis ranah kognitif, afektif dan psikomotor.

Sedangkan menurut pendapat lain yaitu dari Slameto (2010), hasil belajar adalah suatu proses yang dilakukan seseorang untuk memperoleh sesuatu perubahan prilaku yang baru secara keseluruhan sebagai hasil pengalaman sendiri, sehingga hasil perubahan dalam interaksi dengan lingkunganya. Berdasarkan pendapat diatas dapat diambil kesimpulan bahwa yang dimaksud hasil belajar adalah hasil dari usaha dalam kegiatan pembelajaran Ilmu Pengetahuan Alam (IPA) di mana hasil belajar tersebut diperoleh suatu perubahan berupa penguasaan sejumlah pengetahuan, sikap dan keterampilan yang lain yang berbeda beda antara siswa yang satu dengan yang lainya. Pengetahuan dan keterampilan yang dimaksud merupakan usaha belajar siswa yang nampak dalam perubahan tingkah laku sebagai suatu proses hasil belajar yang juga dapat dinilai melalui tes formatif.

\section{Mata Pelajaran IPA}

Mata Pelajaran IPA adalah salah satu mata pelajaran utama pada level SMP dengan bobot 5 jam pelajaran perminggu pada masing-masing kelas VII, VIII dan IX. Mengingat pentingnya mata pelajaran ini, maka seorang guru harus berupaya keras untuk meningkatkan hasil belajar yang maksimal bagi siswanya.

Menurut Sapriati (2009), mata pelajaran IPA yang berhasil akan membuahkan sikap mental yang cerdas, penuh rasa tanggung jawab dari siswa, disertai prilaku:

a. Memperoleh keyakinan terhadap kebesaran Tuhan Yang Maha Esa berdasarkan keberadaan, keindahan dan keteraturan alam ciptaanya.

b. Mengembangkan pengetahuan dan pemahaman konsep-konsep IPA yang bermanfaat dan dapat di terapkan dalam kehidupan sehari-hari.

c. Mengembangkan rasa ingin tahu, sikap positif dan kesadaran tentang adanya hubungan yang saling mempengaruhi antara IPA, lingkungan, teknologi, dan masyarakat.

d. Mengembangkan keterampilan proses untuk menyelidiki alam sekitar, memecahkan dan membuat keputusan.

e. Meningkatkan kesadaran untuk berperan serta dalam memelihara dan menjaga dan melestarikan lingkungan alam

f. Meningkatkan kesadaran untuk menghargai alam dan segala keteraturan sebagai salah satu ciptaan tuhan.

Ada beberapa definisi mengenai Ilmu Pengetahuan Alam salah satunya menurut Sukarno Ilmu Pengetahuan Alam (IPA) adalah: Suatu jenis ilmu pengetahuan teoritis yang diperoleh dengan cara yang khusus, maka cara itu ruparupanya adalah observasi, eksperimentasi, penyimpulan, pembentukan teori, eksperimintasi, observasi, dan demikian seterusnya kait mengkait antara cara satu dengan cara yang lainya. Sedangkan menurut Sapriati (2009), Ilmu Pengetahuan Alam (IPA) merupakan mata pelajaran yang membahas tentang alam secara sistematis untuk menguasai pengetahuan, fakta, konsep, prinsip penemuan dan membangaun diri siswa untuk memiliki sikap ilmiah.

Berdasarkan uraian diatas, maka mata pelajaran Ilmu Pengetahuan Alam (IPA) menekankan pada pemberian pengalaman langsung dan kegiatan praktis untuk mengembangkan potensi agar siswa mampu menjelajahi dan memahami alam sekitar secara ilmiah. Sehingga dapat membantu siswa untuk memperoleh pemahaman yang lebih mendalam tentang alam sekitar. Dalam pempelajaran Ilmu Pengetahuan Alam 
(IPA), pemberian pengalaman belajar secara langsung sangat diterapkan melalui penggunaan dan pengembangan keterampilan proses dan sikap ilmiah dengan tujuan untuk memahami konsep-konsep dan mampu memecahkan masalah. Untuk memahami IPA haruslah melalui pemahaman dari berbagai segi antara lain sebagai berikut institusi, metode, kumpulan pengetahuan, faktor utama untuk memelihara dan mengembangkan produksi dan faktor utama yang mempengaruhi kepercayaan dan sikap manusia terhadap alam semesta dan manusia. Dalam pembelajaran IPA dapat meningkatkan dan mengembangkan kemampuan metakognisi siswa (Ermin, 2021).

\section{METODE PENELITIAN}

\section{Subyek Penelitian}

Subyek penelitian tindakan kelas ini adalah siswa kelas IXb di SMPN 4 Monta pada semester genap Tahun Pelajaran 2020/2021 sebanyak 29 siswa, yang terdiri dari 12 siswa perempuan dan 17 siswa laki-laki.

\section{Waktu Penelitian}

Penelitian tindakan kelas ini dibagi menjadi dua siklus, di awali dengan prasiklus, siklus I dan siklus II, selama 3 bulan. Pada prasiklus yang dilaksanakan pada hari Kamis tanggal 8 Januari 2021, siklus I dilaksanakan pada hari Selasa tanggal 12 Januari 2021 sedangkan untuk siklus II dilaksanakan pada hari Selasa tanggal 23 Maret 2021.

\section{Tempat}

Adapun tempat penelitian tindakan kelas ini dilaksanakan di SMPN 4 Monta pada semester Genap Tahun Pelajaran 2020/2021 pada pokok bahsan Tanah dan Keberlangsungan Kehidupan.

\section{Langkah-langkah pelaksanaan}

Langkah-langkah awal dalam penyusunan Penelitian Tindakan Kelas (PTK) terdapat empat tahap yaitu perencanaan, acting (pelaksanaan), observasi (pengamatan), dan refleksi. Berikut ini adalah gambar keempat langkah dalam PTK:

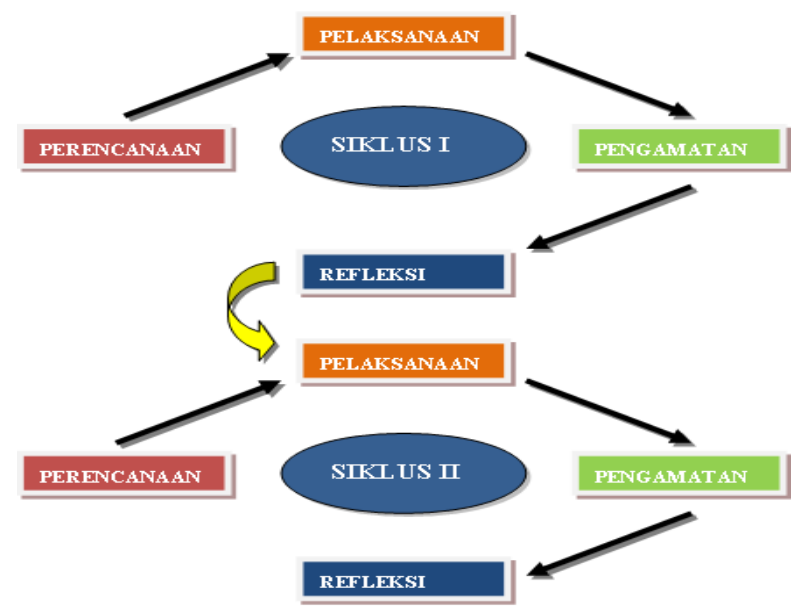

Gambar 1. Alur pelaksanaan PTK Model Kemmis dan Taggart (Trianto, 2011) 

dari:

Rancangan penelitian tindakan yang akan dilaksanakan setiap siklusnya terdiri a. Perencanaan

Langkah pertama adalah melakukan perencanaan secara matang dan teliti. Dalam perencanaan PTK, terdapat tiga kegiatan dasar, yaitu identifikasi masalah, merumuskan masalah, dan pemecahan masalah. Pada masing-masing kegiatan, terdapat sub-sub kegiatan yang sebaiknya dilaksanakan untuk menunjang sempurnanya tahap perencanaan.

b. Pelaksanaan

Pelaksanaan adalah menerapkan apa yang telah direncanakan pada tahap satu, yaitu bertindak di kelas.

c. Pengamatan

Alat untuk mendata seberapa jauh efek tindakan telah mencapai sasaran. Pada langkah ini, penelitian harus menguraikan jenis data yang dikumpulkan, cara pengumpulkan, dan alat atau instrumen pengumpulan data (tes, angket/observasi, dan lain-lain).

d. Refleksi

Kegiatan untuk mengemukakan kembali apa yang telah dilakukan. Dalam hal ini, penelitian seolah memantulkan pengalamannya ke cermin, sehingga tampak jelas penglihatannya, baik kelemahan dan kekurangannya (Suyadi, 2015:50-64).

Arikunto (2009) mengemukakan bahwa pada tahap ini sangat tepat dilakukan ketika guru pelaksana sudah selesai melakukan tindakan, kemudian berharap dengan peneliti untuk mendiskusikan implementasi rancangan tindakan, mencatat hasil observasi dan pelaksanaan pmbelajaran, evaluasi hasil observasi, dan analisis hasil pembelajaran, memperbaiki kelemahan siklus I pada siklus II.

Hasil refleksi berupa refleksi terhadap perencanaan yang telah dilaksanakan tersebut, yang akan dipergunakan untuk memperbaiki kinerja guru pada tahap siklus II dan seterusnya.

\section{Teknik Pengumpulan Data}

\section{a. Observasi}

Menurut Margono observasi "sebagai teknik pengumpulan data mempunyai ciri yang spesifik bila dibandingkan dengan tehnik wawancara. Observasi adalah pengamatan dan pencatatan secara sistematis terhadap gejala yang tampak pada objek penelitian". Observasi yang digunakan digunakan dalam penelitian ini yaitu untuk mengamati aktivitas-aktivitas siswa dalam proses pembelajaran secara langsung, guna untuk melengkapi data-data kuantitatif dengan melalui pencatatanpencatatan lembar observasi.

b. Tes Hasil Belajar

Tes hasil belajar adalah "suatu tes yang mengukur prestasi seseorang dalam suatu bidang sebagai hasil proses belajar yang khas, yang dilakukan secara sengaja dalam bentuk pengetahuan, pemahaman, keterapilan, sikap dan nilai”. Tes hasil belajar ini digunakan peneliti untuk mengukur hasil belajar IPA siswa kelas IXb dengan pokok bahasan Tanah dan Keberlangsungan Kehidupan dengan kriteria ketuntasan minimum (KKM) pada mata pelajaran Ilmu Pengetahun Alam (IPA), yaitu 70. Tes yang diberikan berupa posttes. 


\section{c. Dokumentasi}

Dokumentasi adalah "metode yang digunakan untuk memperoleh dari sumber tertulis atau dokumen-dokumen, baik berupa buku-buku, majalah, peraturanperaturan, notulen rapat, catatan harian dan sebagainya". Berdasarkan pendapat tersebut jelaslah bahwa yang dimaksud dengan dokumentasi adalah berupa metode pengumpulan data yang digunakan dalam suatu penelitian dengan cara mencatat beberapa masalah-masalah yang sudah didokumentasikan oleh guru.

\section{Analisis Data}

Metode analisis data yang digunakan dalam penelitian ini adalah melalui data kualitatif dan kuantitatif. Data kuantitatif diperoleh melalui tes hasil belajar, sedangkan data kualitatif diperoleh dari observasi. Setelah data diperoleh maka dilakukan analisis melalui proses reduksi data kemudian paparan data dan yang terahir dilakukan penarikan kesimpulan.

a. Analisis Kuantitatif

Analisis data ini dihitung dengan menggunakan rumus statistik sederhana untuk mengetahui hasil belajar siswa seperti berikut:Untuk menghitung nilai rata-rata digunakan rumus:

b. Analisis Kualitatif

$$
\begin{aligned}
& \quad X=\frac{\sum x}{n} \\
& \text { Keterangan: } \\
& X=\text { Rata-rata nilai } \\
& \sum x=\text { Jumlah semua nilai } \\
& n=\text { Jumlah Data }
\end{aligned}
$$

Analisis kualitatif dilakukan untuk menarik kesimpulan melalui lembar observasi.Hasil observasi dicatat dalam instrument lembar observasi. Data yang terkumpul dari lembar observasi dianalisis secara kualitatif dengan pendekatan induktif. Aktivitas-aktivitas belajar siswa tersebut dapat diprosentasikan dengan rumus sebagai berikut:

Keterangan:

$$
\mathrm{P}=\frac{\mathrm{F}}{\mathrm{N}} \times 100 \%
$$

$\mathrm{P}=$ Angka Prosentase

$\mathrm{F}=$ Frekuensi yang sedang dicari prosentasenya

$\mathrm{N}=$ Jumlah frekuensi atau banyaknya individu

\section{HASIL DAN PEMBAHASAN}

\section{Hasil Penelitian}

\section{Hasil Belajar Prasiklus}

Berdasarkan hasil tes formatif pembelajaran prasiklus terhadap 29 orang siswa diperoleh hasil yang jauh dari harapan, karena masih banyak siswa yang hasilnya masih dibawah KKM. Ketuntasan yang harus dicapai siswa yaitu 70. Hasil tes formatif prasiklus dapat dilihat dari Tabel 1. 
Tabel 1. Data Hasil Belajar Siswa Prasiklus

\begin{tabular}{|c|l|c|}
\hline No & \multicolumn{1}{|c|}{ Aspek } & Deskripsi \\
\hline 1 & Jumlah Siswa yang ikut Tes & 29 Orang \\
\hline 2 & Jumlah Siswa yang Tuntas & 8 Orang $(27,58 \%)$ \\
\hline 3 & Jumlah Siswa yang tidak Tuntas & 21 Orang $(72,42 \%)$ \\
\hline 4 & Jumlah Nilai & 1600 \\
\hline 5 & Nilai Tertinggi & 80 \\
\hline 6 & Nilai Terendah & 20 \\
\hline 7 & Rata-Rata & 55,17 \\
\hline
\end{tabular}

Tabel 1 menunjukkan bahwa nilai tertinggi yang diperoleh siswa adalah 80 dan nilai terendah 20. Nilai rata-rata yang dicapai adalah 55,17. Data hasil belajar siswa prasiklus dapat digambarkan grafik sebagai berikut:

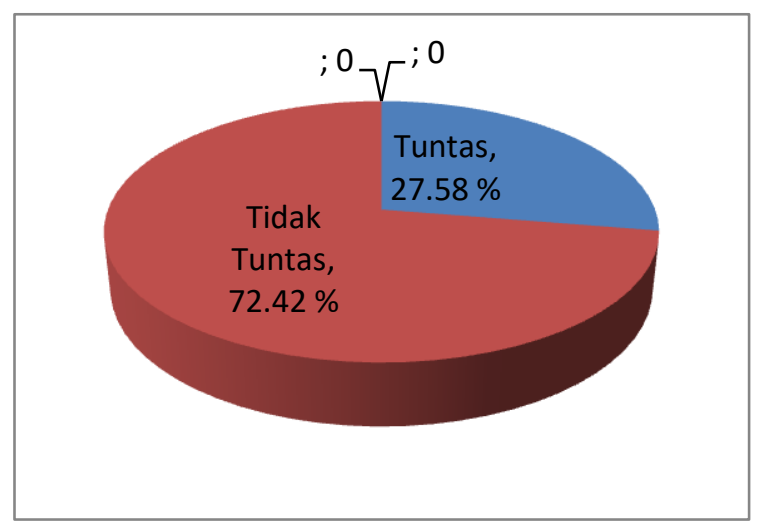

Gambar 2. Diagram Ketuntasan Hasil Belajar Siswa Prasiklus

Dari diagram di atas dapat dilihat bahwa siswa yang telah tuntas sebanyak 8 siswa dengan presentase $27,58 \%$ dan siswa yang tidak tuntas sebanyak 21 siswa dengan presentase $72,42 \%$. Tidak tuntasnya siswa dalam hasil belajar tersebut adalah siswa kurang memperhatikan pelajaran yang diberikan oleh guru. Dari penyebab tersebut untuk menumbuhkan semangat dan mempermudah siswa untuk memahami materi tanah dan keberlangsungan kehidupan maka perlu dilakukan perbaikan pembelajaran dengan penerapan pembelajaran berdiferensiasi. Perbaikan pembelajaran tersebut dilakukan melalui penelitian tindakan kelas dengan dua tahap. Pembelajaran siklus I dan siklus II.

\section{Hasil belajar Siklus I}

Setelah dilakukan pembelajaran pada siklus I, berikut adalah hasil belajar IPA siswa siklus I dengan penerapan pembelajaran berdiferensiasi .

Tabel 2. Data Perolehan Hasil Belajar Siswa Siklus I

\begin{tabular}{|c|l|c|}
\hline No & \multicolumn{1}{|c|}{ Aspek } & Deskripsi \\
\hline 1 & Jumlah Siswa yang ikut Tes & 29 Orang \\
\hline 2 & Jumlah Siswa yang Tuntas & 15 Orang $(51,72 \%)$ \\
\hline 3 & Jumlah Siswa yang tidak Tuntas & 14 Orang $(48,28 \%)$ \\
\hline 4 & Jumlah Nilai & 1930 \\
\hline 5 & Nilai Tertinggi & 90 \\
\hline 6 & Nilai Terendah & 50 \\
\hline 7 & Rata-Rata & 66,55 \\
\hline
\end{tabular}




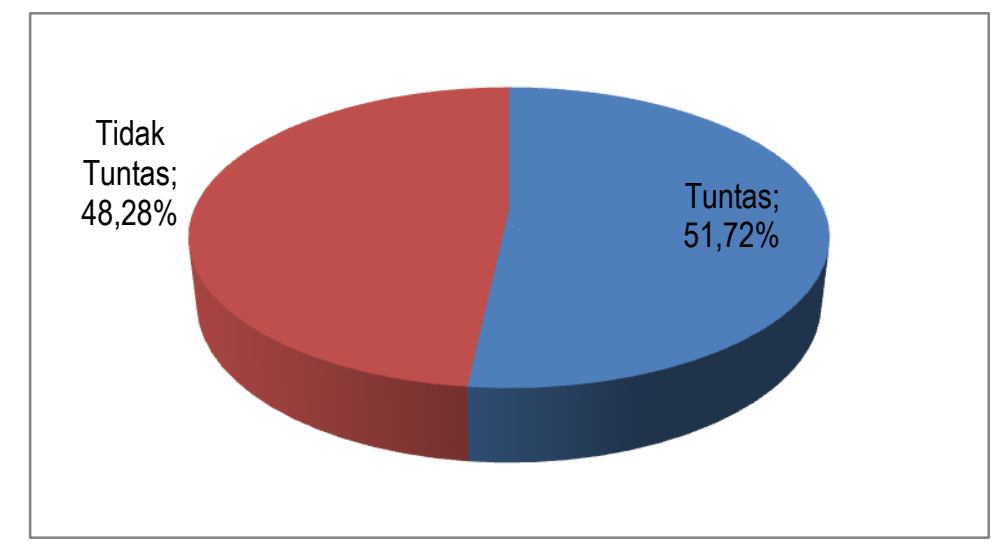

Gambar 3. Diagram Ketuntasan Hasil Belajar Siswa Siklus I

Dari diagram di atas dapat dilihat bahwa dari 29 siswa yang telah tuntas sebanyak 15 siswa dengan presentase $51,72 \%$ dan siswa yang tidak tuntas sebanyak 14 siswa dengan presentase $48,28 \%$.

\section{Hasil Belajar Siswa Siklus II}

Setelah melaksanakan pembelajaran pada siklus II berikut adalah hasil belajar IPA siswa siklus II dengan penerapan pembelajaran berdiferensiasi.

Tabel 3. Data Perolehan Hasil Belajar Siswa Siklus II

\begin{tabular}{|c|l|c|}
\hline No & \multicolumn{1}{|c|}{ Aspek } & Deskripsi \\
\hline 1 & Jumlah Siswa yang ikut Tes & 29 Orang \\
\hline 2 & Jumlah Siswa yang Tuntas & 28 Orang $(96,55 \%)$ \\
\hline 3 & Jumlah Siswa yang tidak Tuntas & 1 Orang $(3,45 \%)$ \\
\hline 4 & Jumlah Nilai & 2320 \\
\hline 5 & Nilai Tertinggi & 100 \\
\hline 6 & Nilai Terendah & 50 \\
\hline 7 & Rata-Rata & 80 \\
\hline
\end{tabular}

Tabel diatas menunjukkan bahwa nilai tertinggi yang diperoleh siswa yaitu 100 sedangkan nilai terendah yaitu 50. Nilai rata-rata yang dicapai siswa adalah 80 . Data hasil belajar siswa siklus II dapat digambarkan dalam diagram berikut:

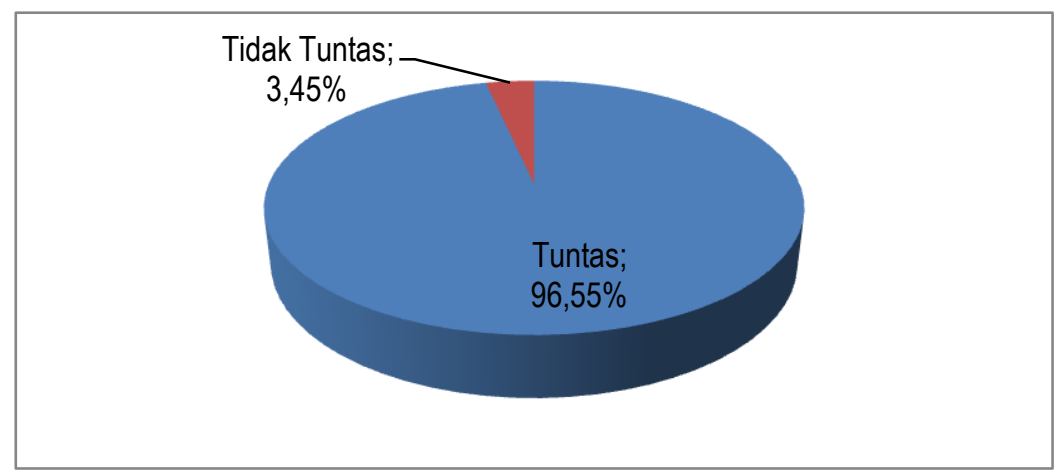

Gambar 4. Diagram Ketuntasan Hasil Belajar Siswa Siklus II

Dari diagram di atas dapat dilihat bahwa siswa yang telah tuntas sebanyak 28 siswa dengan presentase ketuntasan $96,55 \%$ dan siswa yang belum tuntas sebanyak 1 siswa dengan presentase $3,45 \%$. 


\section{Pembahasan Hasil Penelitian}

Mengacu pada tahap-tahap kegiatan persiklus, dapat hasil penelitian di atas dapat dijabarkan sebagai berikut.

\section{Perencanaan}

Penerapan pembelajaran berdiferensiasi yang dikhususkan pada pokok bahasan tanah dan keberlangsunagn kehidupan dipilih sebagai strategi pemecahan masalah yang coba penulis hadirkan dengan memberikan beragam cara agar memahami informasi baru untuk semua siswa dalam komunitas ruang kelasnya yang beraneka ragam, termasuk cara untuk: mendapatkan konten; mengolah, membangun, atau menalar gagasan; dan mengembangkan produk pembelajaran dan ukuran penilaian sehingga semua siswa di dalam suatu ruang kelas yang memiliki latar belakang kemampuan beragam bisa belajar dengan efektif. Proses mendiferensiasikan pelajaran dilakukan untuk menjawab kebutuhan, gaya, atau minat belajar dari masing-masing siswa.

Berdasarkan pada pertimbangan diatas, penulis yakin bahwa dengan diterapkannya pembelajaran berdiferensiasi yang dikhususkan pada pokok bahasan tanah dan keberlangsungan kehidupan pada siswa yang mengalami kesulitan dalam memahami pembelajaran tersebut dapat lebih termotivasi untuk terlibat secara aktif dalam proses pembelajaran sesuai dengan tingkat kesiapan siswa (readiness), minat siswa dan profil belajar dari siswa itu sendiri.

\section{Pelaksanaan}

Sesuai dengan proses pelaksanaann di dalam RPP yang telah disusun, selama proses pembelajaran berlangsung pada prasiklus, aktivitas siswa hanya sebatas mengamati slide saja. Pada siklus I, aktivitas siswa masih terbatas pada mengamati slide dan video yang ditayangkan melalui LCD Proyektor (diferensiasi konten), dan untuk kegiatan demonstrasi peran tumbuhan untuk mencegah erosi tanah (diferensiasi Proses), hasilnya siswa masih pasif untuk melakukan kegiatan tersebut, hanya beberapa siswa saja yang mau ikut kegiatan demonstrasi tersebut, kebanyakan hanya duduk diam saja, sedangkan untuk diferensiasi produknya belum kelihatan. Sedangkan pada siklus II, setelah mengamati slide dan video tentang peran tanah bagi kehidupan, pada saat kegiatan demonstrasi peran tumbuhan untuk mencegah erosi tanah, hampir semua siswa ikut bagian dalam kegiatan ini, dan bahkan kondisi kelas terkesan ribut/ramai. Untuk diferensiasi konten, proses dan produknya terpenuhi semua.

\section{Pengamatan}

Berdasarkan hasil analisis pengumpulan data maka diperoleh kesimpulan data hasil belajar. Rekapitulasi hasil belajar siswa per siklus melalui penerapan pembelajaran berdiferensiasi dapat dilihat dari tabel berikut ini:

Tabel 4. Rekapitulasi Hasil Belajar Siswa

\begin{tabular}{|c|c|c|c|c|c|}
\hline \multirow{2}{*}{ Uraian } & \multicolumn{2}{|c|}{ Siswa Tuntas } & \multicolumn{2}{c|}{ Siswa Tidak Tuntas } & \multirow{2}{*}{ Rat-rata } \\
\cline { 2 - 5 } & Frekuensi & \% & Frekuensi & \% & \\
\hline Prasiklus & 8 & 27,58 & 21 & 72,42 & 55,17 \\
\hline Siklus I & 15 & 51,72 & 14 & 48,28 & 66,55 \\
\hline Siklus II & 28 & 96,55 & 1 & 3,45 & 80 \\
\hline
\end{tabular}




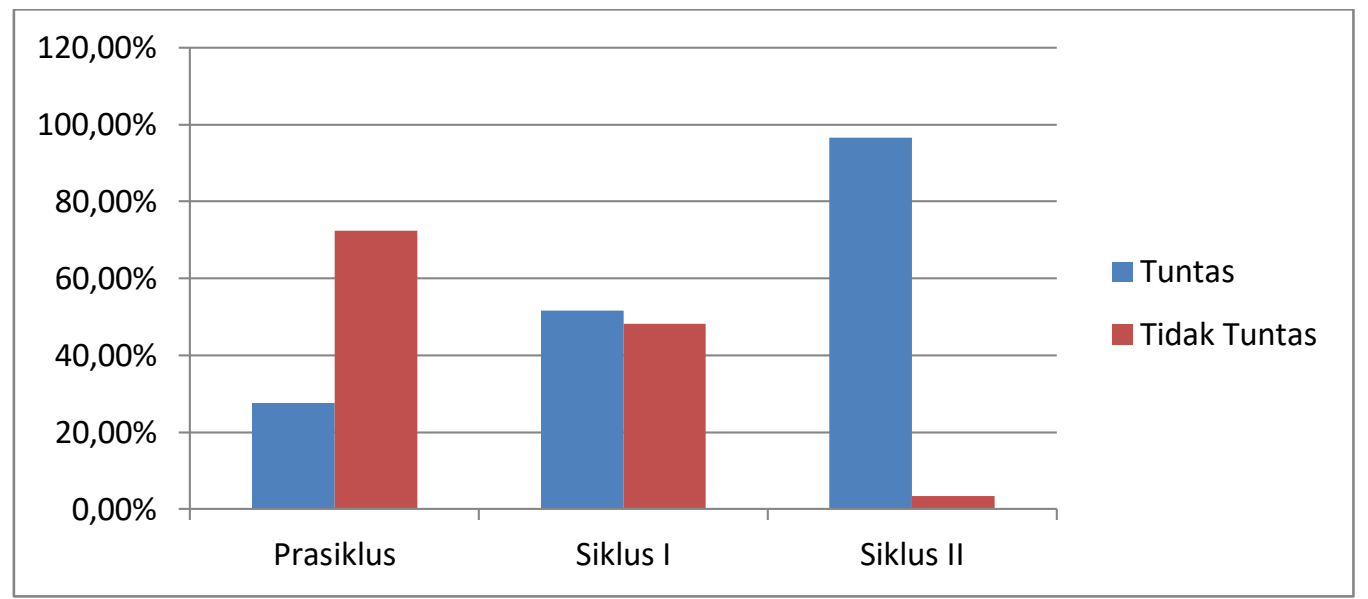

Gambar 5. Diagram Perbandingan Prasiklus, Siklus I dan Siklus II

Dari perbandingan diatas dapat dilihat bahwa pada prasiklus siswa yang telah tuntas sebanyak 8 siswa dengan presentase $27,58 \%$ dan siswa yang tidak tuntas sebanyak 21 siswa dengan prsentase $72,42 \%$, siklus I siswa yang telah tuntas sebanyak 15 siswa dengan presentase $51,72 \%$ dan siswa yang tidak tuntas sebanyak 14 siswa dengan presentase $48,28 \%$, dan siklus II yang telah tuntas sebanyak 28 siswa dengan presentase $96,55 \%$ dan siswa yang tidak tuntas sebanyak 1 siswa dengan presentase 3,45 .

Dari penelitian dan pembahasan menjelaskan bahwa penerapan pembelajaran berdiferensuiasi dapat meningkatkan hasil belajar IPA siswa khususnya pada materi tanah dan keberlangsunagn kehidupan. Hasil evaluasi belajar menunjukkan adanya peningkatan pada pra siklus presentase ketuntasan belajar siswa adalah 27,58\% pada siklus I meningkat $51,72 \%$ dan pada siklus II menjadi $96,55 \%$.

Keberhasilan peningkatan hasil belajar siswa IPA materi tanah dan keberlangsungan kehidupan melalui penerapan pembelajaran berdiferensiasi pada siswa kelas IXb SMPN 4 Monta ditentukan oleh beberapa faktor. Faktor-faktor tersebut yaitu faktor internal dan faktor eksternal. Faktor internal yaitu faktor yang berasal dari dalam meliputi, inteligensi, minat serta motivasi yang dibangun diri sendiri. Kesulitan satu siswa yang nilainya belum tuntas dikarenakan faktor intelegensinya kurang baik, karena siswa tersebut berkebutuhan khusus (idiot). Selain itu, siswa tersebut kurang fokus dalam mengikuti pembelajaran. Sedangkan faktor eksternal yaitu faktor yang berasal dari luar. Faktor eksternal dominan pada penelitian ini adalah lingkungan sekolah. Hal ini terbukti bahwa adanya peningkatan hasil belajar siswa setelah salah satu komponen dari lingkungan sekolah diperbaiki. Komponen tersebut yaitu cara penyajian materi dengan penerapan pembelajaran berdiferensisasi. Cara penyajian materi dengan penerapan pembelajaran berdiferensisasi mampu meningkatkan hasil belajar siswa. Hal ini dibuktikan dari peningkatan hasil rata-rata setiap siklusnya. Pada prasiklus nilai rata-rata yaitu 55, 17. Nilai rata-rata tersebut meningkat pada siklus I menjadi 66,55. Kemudian pada siklus II nilai rata-rata yaitu 80. Jadi berdasarkan hasil penelitian dan pengamatan siklus I ke siklus II mengalami kenaikan yang baik dari awal pembelajaran pada saat penerapan pembelajaran berdiferensiasi pada mata pelajaran IPA materi tanah dan keberlangsungan kehidupan, dalam pelaksanaan hasil siklus II dengan hasil yang diperoleh lebih baik dibandingkan dengan hasil siklus I, dengan begitu menunjukkan 
pemahaman siswa dalam belajar sehingga memenuhi hasil rata-rata nilai prestasi belajar siswa sesuai indikator keberhasilan siswa yang dicapai.

4. Refleksi

Pada prasiklus belum terlihat aktivitas siswa, pada siklus I kegiatan siswa baru terbatas mengamati slide dan video yang ditayangkan oleh guru melalui LCD dan proyektor, dan sebagian siswa sudah ada yang melakukan kegiatan demonstrasi peran tumbuhan untuk mencegah terjadinya erosi tanah, meskipun belum ada produk yang dihasilkan pada siklus ini. Sedangkan pada siklus II, selain mengamati slide dan video, siswa juga sudah mau melakukan kegiatan demonstrasi peran tumbuhan untuk mencegah terjadinya erosi tanah tersebut, dan sudah ada produk yang dihasilkan pada siklus ini, produk tersebut berupa rangkuman-rangkuman kecil siswa pada saat kegiatan pembelajaran berlangsung, dan ada juga yang membuat adalam bentuk tabel pengamatan.

Kelebihan dari setiap siklus, penulis mengawali proses belajar mengajar dengan menayangkan slide dan video yang menarik. Kekurangan dari siklus I, disebabkan oleh efisiensi waktu yang kurang maksimal, terlalu banyak dihabiskan pada penanyangan slide dan video, dan pada kegiatan demonstrasi guru hanya mengarahkan pada siswa agar melakukan kegiatan tersebut sendiri-sendiri, sedangkan pada siklus II, guru mengarahkan siswa untuk melakukan demonstrasi berdasarkan kelompok gaya belajar dari siswa.

\section{KESIMPULAN}

Berdasarkan hasil penelitian dan pembahasan dapat disimpulkan bahwa penerapan pembelajaran berdiferensiasi dapat meningkatkan hasil belajar IPA materi tanah dan keberlangsungan kehidupan pada siswa kelas IXb semester genap di SMPN 4 Monta Tahun Pelajaran 2020/2021. Peningkatan hasil belajar ini ditunjukan dari peningkatan hasil belajar pada pra siklus, siklus I dan siklus II dengan jumlah siswa kelas IXb semester genap di SMPN 4 Monta sejumlah 29 siswa dengan KKM penetapan sekolah yaitu 70. Pada kegiatan pra siklus jumlah siswa yang tuntas adalah 8 siswa $(27,58 \%)$, sedangkan siswa yang belum tuntas 21 siswa $(72,42 \%)$, dengan nilai rata-rata 55,17. Pada siklus I siswa mengalami peningkatan jumlah siswa yang tuntas 15 siswa $(51,72 \%)$ sedangkan siswa yang belum tuntas berjumlah 14 siswa $(48,28 \%)$ dengan nilai rata-rata 66,55. Kemudian pada siklus II ini mengalami peningkatan yang sangat tinggi dibandingkan dengan siklus sebelumnya yaitu siswa yang sudah mencapai KKM berjumlah 28 siswa (96,55\%), sedangkan siswa yang belum tuntas berjumlah 1 siswa $(3,45 \%)$ dengan nilai rata-rata 80 .

Dalam penerapan pembelajaran berdiferensiasi ini dapat meningkatkan hasil belajar siswa dari target pencapaian KKM yang telah ditetapkan, pada Mata Pelajaran IPA Pokok Bahasan Tanah Dan Keberlangsungan Kehidupan Di Kelas IXb Semester Genap SMP Negeri 4 Monta Tahun Pelajaran 2020/2021. Maka PTK ini dinyatakan berhasil.

\section{SARAN}

Saran yang dapat diambil dari hasil penelitian ini, bagi siswa yang hasil belajarnya sudah mencapai ketuntasan dan aktif dalam pembelajaran untuk dapat mempertahankan atau meningkatkan hasil belajarnya. Bagi siswa yang hasil 
belajarnya belum mencapai ketuntasan untuk dapat terus belajar dan berusaha. Kemudian bagi guru, penerapan pembelajaran berdiferensiasi sebaiknya digunakan pada pembelajaran IPA karena terbukti mampu meningkatkan hasil belajar; memberikan motivasi serta membangkitkan semangat belajar siswa yang akhirnya dapat meningkatkan hasil belajar siswa; pemberian penguatan kesimpulan disetiap akhir pelajaran lebih ditekankan kembali supaya membuat siswa lebih memahami materi yang disampaikan oleh guru, dan; menciptakan suasana kelas yang menarik disetiap pembelajaran, misalnya membuat media pembelajaran yang kreatif dan inovatif sehingga akan tercipta suasana kelas yang menyenangkan. Selanjutnya, bagi sekolah agar dapat menyediakan sarana dan prasarana sebagai pendukung dalam proses kegiatan belajar mengajar.

\section{DAFTAR PUSTAKA}

Andini, D. W. (2016). "Differentiated Instruction": Solusi Pembelajaran dalam Keberagaman Siswa di Kelas Inklusif. Trihayu, 2(3), 259034.

Dimyati dan Mudjiono. (2009). Belajar dan Pembelajaran. Jakarta: Rineka Cipta

Ermin, E. (2021). Analisis Keterampilan Metakognisi Siswa Pada Mata Pelajaran IPA Biologi di SMP Kota Ternate. Jurnal Pendidikan dan Pembelajaran Indonesia (JPPI), 1(1), 56-60.

LMS Modul 2.1 PGP (2020). https://bantuan.simpkb.id/books/simlms-pgpinstruktur/ch01/1-1-cara-akses-lms.html

Sapriati dkk, (2009). Pembelajaran IPA di SD, Jakarta: Universitas Terbuka

Slameto. (2010). Belajar dan faktor-faktor yang Mempengaruhinya. Jakarta: PT. Rineka Cipta Amelia,

Suryosubroto. (2009). Proses Belajar Mengajar di Sekolah. Jakarta: Rhineka Cipta. Usman. User. 2008. Menjadi Guru Profesional. Bandung: PT Remaja Rosdakarya

Sutarto \& Syarifuddin. (2013). Desain Pembelajaran Matematika. Yogyakarta: Samudra Biru.

Suyadi, S. (2015). Desain Kurikulum Perguruan Tinggi Mengacu Kerangka Kualifikasi Nasional Indonesia. PT. Remaja Arikunto, Suharsimi. (2009). Penelitian Tindakan Kelas. (Jakarta: Bumi Aksara)

Tomlinson, C. A. (2001). How to differentiate instruction in mixed-ability classrooms. ASCD. Tomlinson. (Modul 2.1 PGP, 2020)

Trianto. (2011). Model Pembelajaran Terpadu Konsep, Strategi dan Implementasinya dalam Kurikulum Tingkat Satuan Pendidikan (KTSP), Jakarta : Bumi Aksara. 